This item was submitted to Loughborough's Research Repository by the author.

Items in Figshare are protected by copyright, with all rights reserved, unless otherwise indicated.

\title{
Here, there, everywhere: the ubiquitous geographies of heteronormativity
}

PLEASE CITE THE PUBLISHED VERSION

PUBLISHER

(C) Blackwell Publishing Ltd

VERSION

AM (Accepted Manuscript)

LICENCE

CC BY-NC-ND 4.0

REPOSITORY RECORD

Hubbard, Phil. 2019. "Here, There, Everywhere: The Ubiquitous Geographies of Heteronormativity". figshare. https://hdl.handle.net/2134/4408. 
This item was submitted to Loughborough's Institutional Repository (https://dspace.lboro.ac.uk/) by the author and is made available under the following Creative Commons Licence conditions.

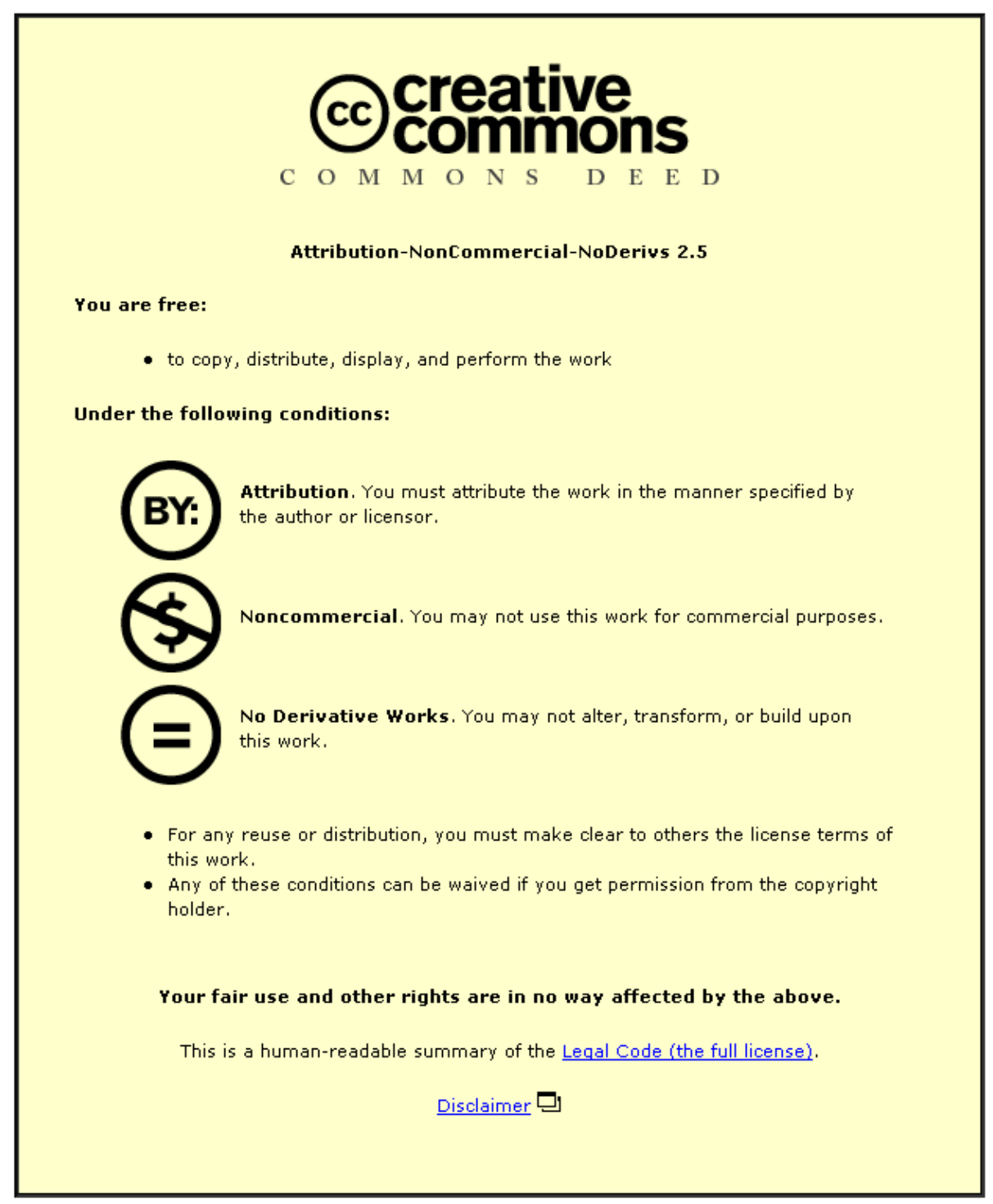

For the full text of this licence, please go to: http://creativecommons.org/licenses/by-nc-nd/2.5/ 
1 Here, there, everywhere:

2 the ubiquitous geographies of heteronormativity

3

4

\section{Phil Hubbard}

Abstract: From its first tentative forays into questions of gay and lesbian residence, the discipline of geography has made increasingly important contributions to literatures on sexual identities, practices and politics. In this paper, I seek to highlight the breadth and depth of contemporary work on sexuality and space by exploring the contributions made by geographers to the theorization of heteronormativity. Specifically, this paper explores how heterosexual norms are maintained and performed spatially, noting the increasing body of work which moves beyond examination of heterosexuality's Other (i.e. homosexuality) to consider the multiple desires and bodies that can be accommodated within the category 'heterosexual'. Moving from urban to rural contexts, this paper hence reviews literatures detailing how particular heterosexual practices are rendered normal, concluding that this literature is usefully shifting from a focus on identity and community to questions of practice and performance. 


\section{Introduction}

3 Long marginalized in the academy, studies of sexuality have now

4 become a familiar - if sometimes contested - fixture in the

5 geographical curriculum. The inclusion of sections on geographies

6 of sexualities in major student texts is evidence of this, as is the

7 existence of thriving speciality groups of geographical societies

8 (e.g. Royal Geographical Society or Association of American

9 Geographers) that support the study of sexuality and space. While sexuality was, until relatively recently considered of little relevance

11 to human geography, it now seems absurd to imagine a geography

12 untouched by sexuality studies and queer theory given all this implies about the relationship between bodies, spaces and desires. Indeed, as Brown and Knopp (2003, 313) argue, geographies of sexuality have proved 'an especially potent force' in debates concerning the epistemology, philosophy and methodology of human geography, challenging many taken for granted assumptions about subjectivity, power and representation. Within a decentred social and cultural geography that is always alert to contingency, difference and Otherness, the attention devoted to matters of sexuality is perhaps not surprising; the impact of sexuality studies on economic, political and environmental geographies may be less significant, yet is still palpable.

The emergence of geographies of sexuality as a recognised subdiscipline is thus widely noted, with a recent edited collection Geographies of Sexualities (Browne et al, 2007) - able to reflect on a remarkable 'explosion' of sexuality studies since the first major 
1 edited collection on the subject - Mapping Desire - was published

2 (Bell and Valentine, 1995). But, as this collection stresses, the

3 'institutionalisation' of sexuality studies has involved compromises

4 and conciliations on both sides, not least the watering down of

5 queer political agendas which were intended to profoundly

6 challenge the structures of academia which order, categorise and

7 ultimately discipline knowledge (see Oswin, 2005). In this paper,

8 however, I address another major concern; namely, that

9 geographies of sexuality overwhelmingly focus on the way that

10 spaces are produced as either heterosexual or homosexual, and

11 consequently fail to acknowledge the diverse sexualities that may

12 exist within these broad categories. As will be detailed in this paper, it is hence vital that geographers acknowledge the existence of many different 'heterosexual' practices and spaces (in the same way that they must reject the idea of a monolithic gay identity to explore multiple queer subjectivities).

This paper accordingly reviews the post-millennial literature on sexuality and space to demonstrate that questions of sex and desire infuse all manner of spaces - and not just the 'gay spaces' which have become such a focus for tourism and consumption (as well as academic scrutiny). Throughout, I will focus on heteromormativity as a guiding concept within the literature, recognising its considerable theoretical worth but also arguing that it comes freighted with dangerous assumptions about the nature of sexual identities. As such, I begin by posing the vexed question of whom (or what) is heteronormal. 


\section{The heteronormal: a brief introduction}

3 In all societies, people are classified in all number of ways

4 according to their age, class, race, gender and, inevitably,

5 sexuality. Over time, these classifications take on a truth that

6 makes them seem beyond question, to the extent they become

7 taken for granted. This is especially the case when such social

8 categorisations are related to seemingly indisputable biological

9 facts. For instance, racial classifications are often regarded as valid because they can be mapped onto particular phenotypical

11 features (skin colour especially); classifying people as men or

12 women is also considered normal given individuals can be classified as female or male depending on the basis of their sexual organs. Yet social scientists have sought to expose such acts of people are expected to act in particular ways according to these biologically- sutured designations. Moreover, even the act of classifying on the basis of people's physicality is fraught with difficulty. In relation to gender, for example, there is an ever expanding lexicon required to describe those who do not fall neatly into male/female distinctions, with transgender and intersexed individuals showing that the world does not neatly divide into male/female (or black/white, young/old, able-bodied/disabled etc) (Hemmings, 2002).

These ideas of social construction are highly relevant in the field of sexuality studies (Vance, 1995). Indeed, ideas about sexuality often draw sustenance from the biological 'fact' of someone's anatomical gender. Women, it is assumed, are normally sexually 
1 attracted to men, and vice versa, with procreation and bringing up

2 children seen as fulfilling outcome of 'sexual congress'. The

3 seemingly indisputable fact of reproduction - an egg meeting a

4 sperm - supports the idea that this is the natural (and perhaps

5 'god-given') order of things, and that other sexual possibilities are

6 simply aberrations. This idea hence infuses society, being maintained by sex education in schools, bolstered by social policy and romanticised in popular media, films and pop songs.

There is hence an important tradition in sexuality studies of exploring the discursive and institutional conditions that encourage certain biological differences to become the salient characteristics of sex. It is here that 'queer' critiques come into their own, drawing on post-structural theorists such as Michel Foucault, Jaques Derrida, Giles Deleuze and Luce Irigaray to show that heterosexuality is a regulatory fiction (i.e. an effect of discourse) and the outcome of many representations and knowledges. In the work of Jeffrey Weeks (1989), for example, heterosexuality was exposed as a social practice invented - and subsequently normalized - through the work of health practitioners, therapists, social workers, educationalists and those who claim to be 'sex experts'. Particularly important, perhaps, are those pioneering sexologists who named homosexuality and heterosexuality as distinctive categories of sexual belonging, with the distinguished sexologist Krafft-Ebing, for example, arguing that men possessed both homosexual and heterosexual instinct, and that a man's final sexual preference was determined by the strongest gendered, sexual feeling. Seduction by members of the same-sex was identified as a catalyst to 'permanent homosexuality' with those 
1 men 'unable to control their passions' being 'sucked into an abyss

2 of base, undifferentiated sexuality and drowned in a sea of bestial

3 pleasures' (Krafft-Ebing, 1892 in Brickell, 2006, 431).

5 Most commentators interested in histories of sexuality have

6 focused on the diagnosis and subsequent classification of

7 homosexuality as pathology, perversion or, more benignly, cultural

8 choice. A key argument here is that although sexual acts involving

9 those of the same sex have been evident in all societies since time immemorial, categories of sexual belonging are a more recent

11 'discovery' or, as social constructivists would insist, 'invention'.

12 Accepting that the classification of people as homosexual or heterosexual (or straight/gay, man/women etc) is a social invention

14 is important in the context of struggles for gay, lesbian and

15 transgender rights because it implies these categories can be reinvented. Yet despite multiple attempts to destabilize these sexual categories, it appears that homosexuality remains understood in relation to heterosexuality, with homosexuality deemed Other to a heterosexuality widely represented as normal,

In this sense, heteronormativity is a term that captures the imposition of certain beliefs about sexuality through social institutions and social policies. These ideas concern a 'normative heterosexuality' in which it is assumed individuals' sexual identities conform to a social norm of heterosexual love, sex and reproduction. Far from being one sexual choice among many, this stresses that heterosexuality is culturally hegemonic, with the reproduction of a heterosexual/homosexual binary an important 
1 structuring device subordinating the homosexual at the same time

2 that it institutionalises the heteronormal (Weeks, 2007). Politicians

3 accordingly extol the virtues of the (heterosexual) nuclear family

4 and support it with a range of income tax and other measures,

5 while they often decry recognition of same-sex relationships:

6 'heterosexual relationships are legitimately public, and deserving

7 of recognition; same-sex relationships are not' (Johnson, 2002,

8 325).

Geographers have intervened in these debates in a number of ways, demonstrating that assumptions about normal sexuality are spatially produced and maintained, diffusing from particular sites of knowledge/power (e.g. parliament, the high court, hospitals, schools, clinics) to encompass the social body with varying degrees of success (Mort and Nead, 2003; Rand, 2003). Particular sites of sex education have been explored by geographers in terms of their role in encouraging particular forms of sexual comportment (Thomas, 2004), while the home has been theorized as a site where sexual norms may be regulated through forms of self-governance as well as parental control (Hockey, 2004). Those 'sexual Others' who do not conform to the expectations inscribed in such spaces may feel 'out of place', and experience a range of emotional conflicts that require management and a duplicitous 'presentation of self'.

Yet it is the wider spatial consequences of this Othering that have most interested geographers, with the stigmatization (and even criminalization) of homosexuality seen to encourage a furtive use of space among non-heterosexuals, who may deny their sexuality 
except when in closeted or safe spaces. Spaces where men can meet other men for sex, in view of one another but away from the gaze of the state, law and disapproving heterosexual populations, have hence been identified, with significant literatures emerging on cottaging (Houlbrook, 2000), cruising (Turner, 2005) and public sex environments, both urban (Binnie, 2001; Brown, 2004) and rural (Bell, 2006). Knopp $(2007,23)$ hence conceptualises the 'sexual experiences of queers' as an integral part of the transitory spaces they inhabit: '[s]ocial and sexual encounters with other queers can feel safer in such contexts - on the move, passing through, inhabiting a space for a short amount of time - and a certain erotic (or just social) solidarity can, ironically, emerge from the transient and semi-anonymous nature of such experiences'. This said, much of the literature has focused on the lives of gay men, but there is also an emerging literature on the social and sexual spaces of lesbian women (Valentine, 1993, Browne, 2004; 2007; Nash and Bain, 2007, Muller, 2007) as well as bisexuals (Hemmings, 2002) that picks up themes of spatial transgression and transformation.

The idea that gay, lesbian and other non-heterosexual individuals adopt 'passing' strategies when in public space has been duly noted (Johnson, 2001), albeit that such individuals may use certain ways of dressing and looking (e.g. the 'backward glance') to signal their sexuality to the initiated (Turner, 2003). The development of gay venues, initially discrete but increasingly visible and commercial, has also been mapped by geographers (Knopp and Brown, 2006), the formation of 'gay villages' occurring as a critical mass of venues emerges (Bassi, 2006). 
2 The unspoken assumption in much of the work on non-

3 heterosexual identities is that everyday ('normal') space is

4 perceived, occupied and represented as heterosexual.

5 Homophobia and prejudice is seen to occur in such spaces

6 (Kitchin and Lysaght, 2003); conversely, the creation of

7 increasingly visible gay spaces is regarded as something of a

8 victory on the road to full citizenship rights. The overall significance

9 of such spaces remains debatable, however, with interesting work

10 having been published considering the way such sites are

11 incorporated into heterosexual leisure and entertainment rituals,

12 considering what happens when 'straights' enter gay space

13 (Casey, 2004, Moran et al, 2002). Moreover, the commodification

14 of such gay spaces (and overt attempts to attract the 'pink pound')

15 have attracted a number of critical queer commentaries given it is

16 a particular (and arguably sanitised) version of gay male desire

17 that is inscribed in the landscape (Binnie, 2001; Nast, 2002, Baasi,

18 2006). What is significant about such critiques is that they alert us

19 to the existence of multiple identities and subjectivities, and stress

20 that there is not one gay community, or even one queer

21 movement, but many.

\section{Other heterosexualities}

With the goal of promoting gay and lesbian rights, those working with queer theory have often railed against the heteronormativity that infuses society. Yet some geographers (e.g. Hubbard, 2000, 
1 Binnie, 2007) have begun to question the usefulness of the

2 heteronormative as a concept, suggesting that it forces a variety of

subject positions and practices into simplistic categories of belonging:

The reservations about focusing excessively on dualistic thinking ...imply that it may be particularly important to encourage non-heteronormative constructions of heterosexual identity, rather than seeing heterosexual identity categories as inevitably producing their 'other', namely, subordinated lesbian and gay identities and vice versa. Non-heteronormative heterosexuality would be based on not privileging heterosexual identity over other categories such as gay, lesbian or transgendered identity (Johnson, 2002, 301).

There is an important sense here in which some queer theorists are beginning to assert the importance of queering heteronormality, exposing this not just as a regulatory fiction that represses non-heterosexuals, but as one that imposes a particular heterosexual norm that also marginalises many heterosexual identities and practices (see Katz, 1995; Richardson, 1996, 2004, 2005; Jackson, 1999). Despite the focus on questions of sexual politics, this is not a particularly new argument, as feminist writings at least as far back as the work of Rich (1980) have argued that compulsory heterosexuality imposes forms of gender identification that ostracise those heterosexual women who do not conform to an ideal of femininity (see also Domosh, 1999, on the 'sexing' of feminist geography). Literatures on the regulation of immoral or 'perverse' heterosexualities make this clear, whether these focus 
1 on the historical regulation of single mothers, premarital sex or the

2 selling of sexual services (Bland, 1995). In contrast, less has been

3 said about the ways that dominant heterosexualities have

4 marginalised particular masculine identities and practices, though

5 the way that moral panics are whipped up around figures including

6 bigamists, perpetrators of domestic violence, errant fathers,

7 paedophiles (always it seems, male) and sex tourists suggests

8 dominant notions of heterosex cannot accommodate many

9 expressions of male desire (see Pheonix and Orton, 2005).

11 There is clearly a strong case for opening up the 'black box' of

12 heterosexuality to explore the many possible articulations of

13 heterosexual desire that are included or excluded within a

14 dominant construction of heternormality. Considering the

15 emergence of 'panic figures' and the measures used to regulate

16 excessive, perverse or immoral forms of heterosex is therefore one

17 possible route into mapping the geographies of heterosexuality

18 (Hubbard, 2000). Literatures on prostitution in particular help to

19 clarify how heternormativity is reproduced spatially through the

20 exclusion and containment of commercial sex work away from

21 'family spaces' (the subtext here being that prostitution and

22 pornography threatens to seduce the innocent into immoral sexual

23 practices). Overt policies of zoning and licensing hence exclude brothels, lap dancing clubs and sex shops from the proximity of educational establishments (Papayanis, 2000; Hubbard et al 2007), as well as, it seems, spaces associated with more respectable femininities (Tani, 2002). Yet the sexual double standards evident here (i.e. male sexual promiscuity is normal, but

29 in women it is a sign of disrepute) intersect with notions of class in 
1 complex ways, with 'high-class hookers' imagined to occupy

2 different social worlds than the 'lower class streetwalkers'.

3 Moreover, Bott's (2006) engaging study of women employed as

4 lap-dancers in Tenerife shows that many took up this form of

5 employment to seek respectability (i.e. dissociating themselves

6 from pathologized version of working class femininity). Crucial in

7 this case was the idea that working in the 'respectable' adult

8 entertainment sector distanced workers from the 'dirt' associated

9 with prostitution

11 This implies that the moral contours of commercial sex are

12 constantly shifting. Once largely confined to derelict and somewhat

13 marginal urban sites, male-oriented 'girlie shows' are being

14 reinvented as adult cabaret, and taking their place within the

15 mainstream night-time economy of the Western city (Hubbard et

16 al, 2007). Visitors to sex shows, so long stigmatised as inadequate

17 and even failed men (the 'dirty mac' brigade), are now taken to

18 include respectable business travellers, with sites of commercial

19 sexuality seen to be significant sites of corporate entertainment

20 which welcome both women and men (Holgersson and Svanstrom,

21 2007). This implies a shift in the consumption and production of

22 commercial sexuality that has been accompanied by changing

23 notions of appropriate sexual comportment, described variously as

24 the mainstreaming of 'pornochic' or striptopia (McNair, 2002).

25 Readers of pornographic magazines were once regarded as

26 socially deviant: now, the codes and conventions of porn "become

27 indicators of a sophisticated late-modern sexual sensibility'

28 (McNair, 2002, 77). 
1 Attwood (2005) accordingly explores the emergence of new forms

2 of heterosexuality by charting the changing forms of masculinity

3 represented in British men's lifestyle magazines, and looks at the

4 way in which sexual prowess is scripted as a key component

5 within contemporary masculine identities. Attwood (2005) argues

6 that the migration of soft porn out of sex shops and into readily

7 available magazines (e.g. Nuts, Zoo, Loaded, FHM) is symbolic of

8 a form of modern sexuality that emerged in the 1990s: the 'new

9 laddism'. Unlike some versions of masculinity to the fore in the

10 1980s, particularly the idea of the 'new man' or househusband in

11 touch with his 'feminine' side (Aish, 2001), such representations

12 suggest that it is normal for men to go for nights out with 'the boys'

13 in which excessive consumption of alcohol, forms of competitive

14 homosociality and sexual predation go hand in hand. Though such

15 representations exist in tension with more upmarket

16 representations of masculinity in which style and narcissism are

17 given more importance, Attwood argues they signal a return to a

18 'libidinous heterosexuality' that must be understood as a reaction

19 to the 'narcissism, sexual puritanism, asexuality and inauthenticity

20 associated with the new man, political correctness, feminism, HIV

21 and AIDS' (see also Jackson et al, 2001).

23 In many ways, these images and stories of male sexual prowess inform the rituals of consumption and leisure played out in British city centres every weekend, with alcohol-fuelled and testertoronepumped men performing assertive and often aggressive masculinities when 'out of the town'. Notably, some towns and cities appear to accommodate such sexualised rituals more 
1 comfortably than others: for example, Nayak $(2006,6)$ notes

2 Newcastle's role as a '[p]arty city: a site for excessive drinking and

3 wild stag and hen nights.' Indeed, cities including Newcastle,

4 Nottingham and Leeds have joined traditional seaside resorts

5 (Blackpool, Brighton, Bournemouth) as centres of a stag and hen

6 tourist market worth over $£ 500$ million to the UK annually (Morgan

7 Stanley, 2005). Visits to sites of adult entertainment are customary

8 in such celebrations, which constitute a celebration of the carnal:

9 sex toys are openly paraded, bodies are exposed, cross-dressing

10 is de riguer. Reactions are decidedly mixed: tourist authorities

11 have sometimes claimed to be concerned about the presence of

12 large groups of disorderly men on the streets, suggesting that such

13 groups stigmatise resorts and put off family consumers (e.g. 'Stag

14 parties ruin Blackpool trade', BBC News 24 July 2003; 'Capital

15 crackdown on stag and hen parties is on the cards The Scotsman, 1625 March 2004).

Whether one regards these events/celebrations as harmless fun or, conversely, as profoundly antisocial, it must be conceded that such displays are fairly 'normal' (Grazian, 2007). What is also evident is that the new lad has found his counterpart in the 'ladette', a label connoting women who are 'boisterously assertive', 'sexually aggressive' and drink 'like a man' (Skeggs, 2005; Jackson, 2006). Something of a panic figure for the media (and often woven into accounts of yob culture in binge-drinking Britain), the ladette's existence is suggestive of shifts in expectations of

27 feminine sexual comportment. It is very easy, perhaps, to suggest that the 'new lad' signals a return to the 'bad old days' in which sexism and misogyny were rife, and to label ladettes as traitors to 
1 the feminist cause. Against this, some commentators regard the

2 ladette as having seized phallic power back from men (McRobbie,

3 2006), creating a new heterosexual 'playing field' in which men and women play to the same rules. It is thus possible to read the 'lad's mags' that some regard as sexually regressive as symbolising this new equivalence. Attwood (2005) argues that within the magazines, the (usually scantily clad) female body is displayed to induce male sexual pleasure, but that women are elevated within the magazines to a position equal to that of the male reader. Unlike the well-rehearsed feminist argument of the exploitation of the female body for male pleasure through 'the gaze', Attwood (2005) maintains that there is 'a rough kind of equivalence in the way that sex is narrated here. ... Both crave sex; both are active, hot, wet, eager for more, eager for the same...'. Likewise, many of the academic interpretations of the HBO series Sex and the City suggest that images of sexually assertive women in the media reflect changing expectations of how (and where) women express their sexuality.

In recounting such arguments it is important to remember that there are others who regard the presence of sexualised images of women in the public realm as offensive and intimidating, perpetuating ideas that women are always 'on display' as sexual objects (Rosewarne, 2005). There is of course a rich vein of urban writing which considers the historical role of the city as a site of spectacle, visual pleasure, and (male) voyeurism: as early as the 1800's a serious of publications were produced for urban 'ramblers' in pursuit of pleasure in many forms (Rendell, 2000). The magazines produced during this time - such as The Rambler's 
1 Magazine - invoked real and imagined sexual pleasures of the city,

2 and also published explicit details of where sex workers could be

3 found (Rendell, 2000). In a wider sense, they reflected the fact that

4 consumption in cities (so often imagined to be 'women's work) also

5 concerned men's consumption of women:

Women are exchanged, both socially and symbolically, as commodities with use values (sex and/or child-bearing and rearing) and exchange values (signifiers of male worth in terms of property and commodities)...men organise and display their activities of exchange and consumption, including the desiring, choosing, purchasing and consuming of female commodities, for others to look at in public space (Rendell, 2002, 19)

What many accounts of flaneurialism also highlight is that the 'man about town' not only took pleasure in gazing on women, but also took narcissistic pleasure in being seen. To invoke a more contemporary idiom, we might identify the eighteenth and nineteenth century flaneur as the forerunner of the 'metrosexual', a bicurious male consumer said to 'endorse equal opportunity vanity through cosmetics, softness, hair care products, wine bars, gyms, designer fashion, wealth, the culture industries, finance, cities, cosmetic surgery, David Beckham, and deodorants' (Clarkson, $2005,35)$. A decidedly post-industrial masculine identity, the metrosexual may be as much as a media invention as the lad or ladette, but is none the less real for all that. Indeed, the identification of a 'feminized male' who blurs the visual style of straight and gay in a restless search 'to spend, shop and deep- 
1 condition' poses interesting questions about the ability of the post-

2 industrial, post-Fordist city to foster new masculinities based on an

3 ambivalent relationship to traditional heterosexualities in which

4 men were 'strong and silent' (Craine and Aitken, 2004,

5 Rasmussen, 2006, Sender, 2006).

7 Working through these debates, it seems that the identities and

8 spaces which can be accommodated within normative

heterosexuality are currently and constantly changing.. This suggests that heteronormativity is not a monolithic or unbending structure, but a concept that shifts to encompass different masculine and feminine performances over time. It is perhaps useful here to invoke Butler's notion of a 'heterosexual matrix' to make conceptual sense of what she describes as the 'selfsupporting signifying economy that wields power in the marking off of what can and cannot be thought within the terms of cultural intelligibility' (Butler, 2000, 99-100). In her writing, the heterosexual matrix is described as a distinctly 'masculine sexual economy' in which gender categories support 'gender hierarchy and compulsory heterosexuality' (Butler, 2000, xxviii). This heterosexual matrix enables certain identifications, foreclosing and disavowing others, with 'the repeated stylization of the body' congealing over time to produce 'the appearance of substance, a natural sort of being'. To put this more simply, by repeatedly conforming to ideas as to how men or women are supposed to dress, talk and behave, we naturalise the idea that certain heterosexual identities are normal. Butler's ideas also allow for the possibility of resistance from the dominant forms of sexual performance suggesting that if they repeatedly subvert, parody or 
1 challenge these norms, dominant 'scripts' might change.

4 Heterosex in unsexy spaces

So far, it has been suggested that the study of sexuality and space needs to encompass the spaces of heterosexuality as well as those associated with non-heterosexual and homosexual practices. Yet when talking of the spaces of heterosexuality it is tempting to refer primarily to those spaces of leisure, consumption and nightlife which are overtly sexualised through the rituals of encounter, negotiation and, sometimes, sex itself. Sex shops, red light areas, nightclubs or pubs are all places which we would expect to be studied in relation to theories of sexuality, not least because these are sites which act as foci in debates about sexuality morality. However, Phillips (2006) argues that the construction of hegemonic sexualities occurs not only at points of contestation, but also at quiet, unobtrusive points in everyday practice. Phillips takes the example of railway stations and maritime ports as points of passage, showing that, in the nineteenth century, unaccompanied women passing through such 'unsexy' sites were regarded as at risk, and in need of chaperoning. Guides for the woman traveler advised as to the potential dangers of foreign lands, while certain ways of dressing were discouraged (see also Gerodetii and Bieri, 2006). One can see echoes of this in contemporary travel guides that offer distinctive advice for women travelers replete with assumptions about women's sexuality. And it isn't just when traveling abroad 
1 when women are given advice on how to dress and act: Boyer's

2 (1996; 2003) reflections on women's incorporation in the

3 masculine worlds of work suggests that notions of appropriate

4 heterosexuality also infuse workspaces (see also Longhurst, 2001,

5 on the working body and Tyler and Cohen, 2007, on gendered

6 office politics).

8 These examples show that ideas of appropriate heterosexual conduct are constructed in all manner of sites, and not just those represented as 'sexual' (Nast, 1998). This point has also been made in literatures concerning rural sexualities. Though the countryside is often imagined as a site of sexual stability and heternormativity, away from the sites of sexual experimentation and adult entertainment characteristic of many cities, some have argued that its sexual geographies are a good deal more complex. Variously a haven for gay and lesbian individuals (Phillips et al, 2001), an imagined sexual arcadia (Cook, 2003) potential site of zoophilia (Campbell et al, 2006), and public sex environment (Bell, 2006), these diverse sexualities are often subsumed within representations of masculinity and femininity based on more traditional notions of male activity and female passivity (Hughes, 1997). In the work of Jo Little, this taken-for-granted 'conventional rural heterosexuality' has been theorized as the outcome of any number of social 'projects' that direct the forms of sexual relations entered into by men and women in the rural. For example, Little's (2003) analysis of rural 'bachelor's balls' and attempts to find (female) partners for male farmers (in the TV series The Farmer Wants a Wife) suggests that many rural farmers assess potential sexual partners in terms of their ability to help nurture the 'family' 
1 farm, separating 'city girls' from 'country girls'. As she concludes:

Inscribed in both campaigns, then, were strong beliefs about the association between farming, rural survival, the family and the sorts of women required and, critically, seen as suitable for farming/rural lives. Being interested in a serious relationship, family relationship and permanence, was, it seemed associated with qualities such as being level-headed and down to earth (Little, 2003, 410)

The strong association made between conventional masculinities, femininities and ruralities in this instance suggests parallels can $b$ drawn between the preservation of rural life and the continuation of normal heterosexual identities (Little 2003, 415). Even when the rural body is presented as an object of desire - as in the Women's Institute nude calendar that inspired the film Calendar Girls - It is often represented as engaged in rural pursuits such as jammaking, flower arranging or baking: though not supposed to be taken too seriously, the sexualised representation of a 'homely' body is in marked contrast of more conventional tropes in glamour photography.

Notions of 'nature' and 'the natural body' are clearly in play here, with iterative performances folding nature and heterosexuality back into one another (Little and Paneill, 2007, 187), creating ideas of a rural sexuality that, if not morally superior to that found in the urban, is often deemed to be part of the 'natural order'. Such ideas about the connections between heterosexuality and nature are 
1 also explored in Johnston's (2006) account of wedding tourism in

2 New Zealand. Like stag and hen do's, wedding celebrations are

3 crucial public performances of heterosexuality, with subsequent

4 honeymoons also 'powerful markers of a couple's normality,

5 morality, productivity and appropriate gendered subjectivities'

6 (Johnston 2006, 192). As she writes, when the bride and groom

7 are gathered together into an 'exotic' down-under 'primitive' locale,

8 heterosexuality is enfolded into nature, and nature into

9 heterosexuality; 'the destination wedding entwines sexuality with a sensory appreciation of landscape'. The representation of New

11 Zealand as one of the world's premier nature spaces is especially

12 significant in romanticizing the wedding as well as nature: as such, 13 heterosexuality is made to appear as natural and timeless as the 14 landscape in which it is celebrated.

Studies such as these point to an increasing interest in the role of place in reproducing normative heterosexualities (as well as $(2006,206)$ notes - it is impossible to talk of heterosexual spaces per se, with such spaces being constituted through practice. This suggests that labelling certain spaces (e.g. the suburbs, the rural, exotic resorts) as paradigmatic spaces of heterosexuality is problematic: rather than theorising such spaces as heteronormal, geographers need to explore the heterosexual acts and rituals that give these the appearance of being heteronormal. After all, all manner of sexual practices are possible in different spaces. And, in any case, to speak of people being either heterosexual or homosexual is, as we have seen, highly problematic. Research on 
1 men who sell sex to men, for example, shows that men who

2 identify as heterosexual may sell sexual services to other men

3 (Aggleton, 1996). One could label these individuals as bisexual;

4 however, it is perhaps better to think of sexuality as immanent,

5 defined in the moment, and never easily classified (Conlon, 2004).

6 Indeed, our sexual identities are made up of different encounters

7 and relations which, taken together, constitute our sex life. For

8 most of us, this rarely amounts to a consistent story, and our sex

9 lives are seldom predictable. Hence, even if some of us feel able

10 to identify as straight or gay, which of us can really claim to be

11 'normal'?

\section{Conclusion}

Sexuality studies appear to be firmly on the curriculum of twenty first century human geography. But rather than circling endlessly around the same debates concerning gay ghettos and the spatial expressions of homophobia, current interventions offer a wide purview of sexual geographies. Both heteronormative and homonormative assumptions about space are now routinely bought into question, with studies exploring how the identification of spaces as nominally 'straight' or 'gay' creates exclusions not just

24 along lines of sexuality, but also class, age and ethnicity (Nast, 25 2002; Baasi, 2006; Browne et al, 2007). Yet, as this review has suggested, there remains much that could - and should - be said about the geographies of heterosexuality. Studies of both 'sexy' 
1 and 'unsexy' spaces reveal heterosexuality as a fractured and

2 complex set of practices, albeit with certain performances of

3 masculinity and femininity being deemed normal.

4

5 In this article I have argued that constantly shifting ideas of what is

6 sexually 'normal' are mapped onto, and out, of spaces whose

7 production demands further study. Some of these spaces appear

8 distinctly 'unsexy' at first glance, while others are sites firmly

9 associated with the sensual, the sexual and the erotic. But in either

10 case, it is clear that sex itself should not be ignored, no matter how

11 troubling the relationship between erotics, the body and sexuality

12 might be for geographers (Binnie, 2007). Rather than attempting to

13 map where different sexual communities and identities belong,

14 therefore, the challenge ahead is to consider how sexuality is

15 performed and practised, spatially. 


\section{References}

Aggleton P (ed.) (1996) Men Who sell sex: International perspectives on male prostitution and HIVIAIDS Philadelphia, Temple University Press.

Aish A 2001 Househusbands: the socio-spatial construction of male gender identity, in Limb, M. and C. Dwyer (eds) Qualitative Methodologies for Geographers: issues and debates, London: Arnold, 285-287.

Attwood F 2005 'Tits and arse and fighting' Male heterosexuality in magazines for men International Journal of Cultural Studies 8 83-100.

\section{Bain A and Nash C (2007) The Toronto Women's Bathhouse} Raid: Querying Queer Identities in the Courtroom Antipode 39 1734

Bassi C 2006 Riding the dialectical wares of gay political economy: a story from Birmingham's commercial gay scene. Antipode 38 213-35.

Bell D 2006 Bodies, technologies, spaces: on dogging Sexualities 9 387-407.

Bell D and Valentine G 1995 Mapping desire: geographies of sexualities Routledge, London.

Bell D and Valentine G 1996 Queer country: rural lesbian and gay lives Journal of Rural Studies 11 113-122.

Bell D, Binnie J, Cream J and Valentine G 1994 All hyped up and no place to go. Gender, Place and Culture 1 31-47.

Berg, L.D. and Longhurst, R 2003 Placing masculinities and Geography Gender, Place and Culture 10 351-360

Bernstein E 2004 Desire, demand and the commerce in sex, in E Bernstein and Shaffner, L. (eds) Regulating Sex: The Regulation of Intimacy and Identity Routledge, New York, 101-128.

Binnie J 2001 The erotic possibilities of the city In Bell, D. Binnie, J. Holiday, R. Longhurst, R. and Peace, R. (Eds.) Bodies, Cities, spaces, Pleasure Zones New York, Syracuse 73-119

Binnie J 2007 Sexuality, the erotic and geography in Browne K, Lim J and Brown G (eds) 2007, Geographies of sexualities: theory practices and politics Ashgate, Aldershot, 29-38. 
1 Bland L 1995 Banishing the beast: English feminism and sexual

2 morality, 1885-1914 London, Penguin Books.

3 Bott E 2006 Pole position: migrant women producing Selves

4 through lap-dancing work Feminist Review 83, 23-41

5 Boyer K 1996 What's a girl like you doing in a place like this? A geography of sexual violence in early twentieth century Vancouver. Urban Geography 17 286-293.

Boyer L 2003 Neither Forget Nor Remember Your Sex': Sexual Politics in the Early Twentieth-Century Canadian Office The Journal of Historical Geography 29 203-230.

Brickell C 2006 Sexology, the homo/hetero binary, and the complexities of male sexual history Sexualities 9 423-447.

Brown G 2004 Sites of public homosex, in Lees L (ed) The Emancipatory City London, Sage, 91-107.

Brown M and Knopp L 2003 We're here! We're queer! We're over there, too! Queer Cultural Geographies, in Anderson K, Domosh M, Pile S and Thrift N (eds) Handbook of Cultural Geography Sage, London

Browne K 2004 Genderism and the bathroom problem: rematerialising sexed sites, recreating sexed bodies Gender, Place, Culture 11 331-346

Browne K 2007 (Re)making the Other: heterosexualising everyday space Environment and Planning A 39 996-1014

Browne K, Lim J and Brown G (eds) 2007, Geographies of sexualities: theory practices and politics Ashgate, Aldershot.

Butler J 2000 Gender trouble London, Routledge

Campbell H, Mayfield Bell M and Finney M 2006 Country boys: masculinity and rural life Penn State Press.

Casey M 2004 De-dyking Queer Space(s): Heterosexual Female Visibility in Gay and Lesbian Spaces Sexualities 7 446-461.

Clarkson J 2005 Contesting masculinity's makeover: Queer Eye, consumer masculinity and 'straight-acting' guys Journal of Communication Inquiry 29 235-255

Conlon D 2004 Park Productive Bodies, Performative Spaces: Everyday Life in Christopher Sexualities 7 462-473

Cook M 2003 London and the culture of homosexuality 1885-1914 Cambridge, Cambridge University Press. 
1 Cowen D 2003 From the American lebensraum to the American

2 living room: class, sexuality, and the scaled production of

3 'domestic' intimacy Environment and Planning D - Society and

4 Space $22755-771$.

5 Craine $\mathbf{J}$ and Aitken S 2004 Street fighting: placing the crisis of masculinity in David Fincher's Fight Club Geojournal 59 289-296.

Domosh M 1999 Sexing feminist geography Progress in Human

Geography 23 429-37.

Gerodetti N and Bieri S 2006 (Female hetero)sexualities in transition Feminist Theory 7 69-87.

Grazian D 2007 The Girl Hunt: Urban Nightlife and the

Performance of Masculinity as Collective Activity Symbolic Interaction 30 221-243

Hemmings C 2002 Bisexual spaces: a geography of sexuality and gender Routledge, London.

Holgersson. C and Svanstrom, Y. 2007 Sexual entertainment as corporate entertainment Gender, Work and Organisation forthcoming.

Houlbrook M 2000 The Private World of Public Urinals: London 1918-57 London Journal 25, 43-60.

Hubbard P 2000 Desire/disgust: mapping the moral contours of heterosexuality Progress in Human Geography 24 191-217

Hubbard P 2004 Revenge and injustice in the revanchist city: uncovering masculinist agendas Antipode 36 665-686.

Hubbard P, Matthews R, Scoular $\mathbf{J}$ and Agustin $\mathbf{L}$ forthcoming Men behaving badly? Exploring the gendered geographies of 'adult entertainment Progress in Human Geography

Hughes A 1997 Rurality and cultures of womanhood: domestic identities and moral order in village life. In P. Cloke, editor, Contested countryside cultures. London, Routledge, 123-137.

Jackson C 2006 'Wild' girls? An exploration of 'ladette' cultures in secondary schools Gender and Education 18339 - 360 Jackson P, Stevenson N and Brooks K 2001 Making Sense of Men's Magazines Oxford, Polity.

Jackson S 1999 Heterosexuality in Question London, Sage. Johnson C 2002 Heteronormal citizenship and the politics of passing Sexualities 5 317-331. 
Johnston L 2006 I do down under: naturalising landscapes and love through wedding tourism in New Zealand Acme 5 191-208.

Katz J N 1995 The invention of heterosexuality Chicago, University of Chicago Press.

Kawale R 2004 Inequalities of the heart: the performance of emotion work by lesbian and bisexual women in London, England Social and Cultural Geographies 5 565-581.

Kitchin R and Lysaght K 2003 Heterosexism and the geographies of everyday life in Belfast, Northern Ireland Environment and Planning A 35489 - 510

Knopp L 1995 Sexuality and urban space: a framework for analysis. In D. Bell and G. Valentine, editors, Mapping desire: geographies of sexualities, London, Routledge, 149-162.

Knopp L 2007 From lesbian to gay to queer geographies: Pasts, prospects and possibilities. In Brown, G. Lim, J. And Browne, K. (Eds.) Geographies of sexualities: Theory practices and politics Chichester, Ashgate.

Knopp L and Brown M 2006 Places or Polygons: Governmentality, Scale, and the Census in The Gay and Lesbian Atlas Population, Space \& Place, 12, 211-222.

Lauria M and Knopp L 1985 Towards an analysis of the role of gay communities in the urban renaissance Urban Geography 6 152-169.

Little J 2002 Rural geography: rural gender identity and the performance of masculinity and femininity in the countryside' Progress in Human Geography 26 665-670

Little J 2004 Riding the rural love train Sociologica Ruralis 43 400-417

Little J and Panelli R 2007 Outback romance? A reading of nature and heterosexuality in rural Australia Sociologia Ruralis 47 173-188.

Longhurst R 2001 Bodies Routledge, London.

McNair B 2002 Striptease Culture: Sex, Media and the Democratisation of Desire Routledge, London.

McRobbie A 2006 Cultural studies in question London, Sage.

Mintel Reports 2003 Stag and hen holidays UK London, Mintel.

Moran L, Skeggs B, Tyrer P and Corteen K 2001 Property, 
1 boundary, exclusion: making sense of heteroviolence in safer

2 spaces Social and Cultural Geography 2 407-416.

3 Mort F and Nead L 2003 Introduction - sexual geographies New 4 Formations 37 1-19.

5 Muller T 2007 Performing community: lesbian community in 6 WNBA spaces Social and Cultural Geography

Nast H J 1998 Unsexy geographies Gender, Place and Culture 5, 191-206.

Nast H J 2002 Queer patriarchies, queer racisms, international. Antipode 34 874-904.

Nayak A 2006 Displaced Masculinities: Chavs, youth and class in the Post-industrial city Sociology 40 813-831

Oswin N 2005Towards radical geographies of complicit queer futures ACME 79-86

Papayanis M 2000 Sex and the revanchist city: zoning out pornography in New York. Environment and Planning D - Society and Space 18 341-354.

Phillips R 2006 Unsexy geographies: heterosexuality respectability and the traveller's aid society Acme 5 (2) 163-188

Phillips R, Watt D and Shuttleton D (eds) 2000 De-centring sexualities: politics and representations beyond the metropolis Routledge, London.

Phoenix J and Oerton S 2005 Illicit and Illegal: sex, regulation and social control Cullompton, Willan Press.

Rand E 2003 Breeders on a golf ball: normalizing sex at Ellis Island Environment and Planning D - Society and Space 21 441460.

Rasmussen C E 2006 We're no metrosexuals: identity, place and sexuality in the struggle over gay marriage Social and Cultural Geography 7 807-825

Rendell J 2000 Pursuits, in Pile, S. and Thrift, N. (Eds.) City A-Z London, Routledge.

Rendell J 2002 The pursuit of pleasure London, Athlone.

Rich A 1980 Compulsory heterosexuality and lesbian existence Signs 5 631-660.

Richardson D 1996 Theorizing Heterosexuality: Telling it Straight Buckingham, Open University Press. 
1 Richardson D 2004 Locating sexualities: from here to normality

2 Sexualities 7 391-411.

3 Richardson D 2005 Desiring Sameness? The rise of a neoliberal

4 politics of normalization Antipode 515-535.

5 Robinson V, Hockey J and Meoh A 2004 What I used to do on

6 my mother's knee: spatial and emotional aspects of

7 hetereosexuality in England Gender, Place and Culture 11 417-

8435.

9 Rosewarne L 2005 The men's gallery: Outdoor advertising and

10 public space Women's Studies International Forum 28 67-78.

11 Sender K 2006 Queens for a Day: Queer Eye for the Straight Guy

12 and the Neoliberal Project Critical Studies in Media

13 Communication 23131 - 151

14 Skeggs B 2005 The making of class and gender through

15 visualising moral subject formation Sociology 39 965-983.

Tani S 2002 Whose Place is This Space? Life in the Street Prostitution Area of Helsinki, Finland International Journal of Urban and Regional Research 26, 343-359

Thomas M E 2004 Pleasure and propriety: teen girls and the practice of straight space Environment and Planning D - Society and Space 22773 - 789.

Turner M W 2003 Backward glances: Cruising the queer streets of New York and London Reaktion Books, London.

Tyler M and Cohen L 2007Management in/as Comic Relief: Queer Theory and Gender Performativity in The Office Gender, Work \& Organization

Valentine G 1993 Hetero-sexing space: lesbian perceptions and experiences of everyday spaces Environment and Planning $D$ Society and Space 9 395-413.

Vance C 1995 Social construction theory and sexuality, iln Berger $\mathrm{M}$, Wallis $\mathrm{B}$, and Watson $\mathrm{S}$ (eds.) Constructing Masculinity Routledge, London

Weeks J 1989 Sex, Politics and Society. The Regulation of Sexuality since 1800 Longmans, Harlow 